\title{
Social Welfare System of Republic of Srpska in the Function of Developing a Non- Governmental Network of Support for Children with Disabilities
}

\author{
Ljubo Lepir, PhD \\ Professor at the Department of Social work, Faculty of political science, University of Banjaluka, Bosnia and Herzegovina
}

Dragana Šćepović, PhD

Professor at the Department of Social work, Faculty of political science, University of Banjaluka

Andrea Rakanović Radonjić, MSc

Senior teaching assistant, Department of Social work, Faculty of political science, University of Banjaluka

\begin{abstract}
Children with disabilities represent a significant part of the population of users within Social welfare system in the Republic of Srpska. Number of children with a disability who are registered as users at the centers for social work, and therefore as users of social services, annually range around 3.5 thousand. Their status and support services are defined by the Law on Social Protection, which allows the non-governmental sector to provide services for children with disabilities. The network of non-governmental organizations and consumer associations concerned with providing social support to children with disabilities and their parents began to develop in the late 90s, when they started to form parents' associations in several municipalities. In the past period such associations were formed in almost all the communities in the Republic of Srpska. Their activities are very important for improving social protection in local communities. These associations work together at regional level, in the framework of the Association Persons with Mental disabilities (acronym - MINERALS). The effect of parents' associations is recognized through the development of partnerships with centers for social work on the realization of social protection measures for children with disabilities. Associations have developed new support services such as day care, speech therapy treatments, workshops, self-help groups and etc. Association improved the direct work with children, provide new ways of financing social protection and welfare (project finance), have contributed to the planning of services, developed the partnership model of cooperation, have contributed to the legal solutions; enhance the social sensitivity of the local community to the situation of children with disabilities. This paper presents the development of a network of parents associations of children with disabilities in the Republic of Srpska, legal merits of their work and partnership in the social welfare system, model of community work and the role of associations in the life of the local community. Paper also presents the results of research relating to the general characteristics of a network of associations, members of the association structure, and the types of services provided to the associations, methods of working with customers, quality of partnerships and ways of financing the association.
\end{abstract}

Keywords: Children with disabilities, Republic of Srpska, an association of parents, social services, Social welfare system

\section{Introduction}

Children with disabilities are socially vulnerable group of the population, which required different types of support measures in the community. Their development is in direct correlation with the achieved level of satisfying their needs arising from development difficulties, as well as the possibilities of the community to fulfill those needs. Family, user associations and public institutions create a specific system of social support for children with disabilities in the community. Their action is crucial to achieving quality results of social support. Specifics of the development problems of children determine their needs and support systems affect the quality of satisfying those needs. Such mutual conditionality between development problems, the needs of children and community resources refers to the necessity of coordinated actions between the different actors in the Social welfare system, and in order to ensure a better 
development path of the child with disabilities. Support to children with disabilities is recognized as a different planned intervention measures, organized and implemented in their immediate environment. First of all this relates to measures carried out by parents, communities and institutions of the system. Parents, for its natural role, are the first circle of support. Since their engagement and willingness depend on the results of all other interventions. An important role in providing support to children and parents are resources in their immediate community. Community resources are identified in institutional facilities, amenities and a positive atmosphere which is essential to family of a child with disabilities. Systemic interventions are carried out in different areas of social activities such as health care, education, child protection, rehabilitation and social protection. Social protection as part of a system of social welfare for children with disabilities, is consists of the organizational system, service providers and users themselves. The social welfare system consists of a network of institutions of social protection and measures to be implemented by users. It is determined by the legal and budgetary framework that enables action to protect subjects. For children with disabilities, the social welfare system is one of the key support system through which can be realize different types of intervention aimed at moderating and facilitating their development problems. Service providers are public institutions, nongovernmental organizations and the private homes involved in caring for children with disabilities. Social service providers are professionals, professionals who directly implement measures to support children with disabilities. In addition to children with disabilities, beneficiaries of social protection are their parents as well. Parents or family where children live are the key player in the implementation of support for children with disabilities. Any measure of system support has a chance of failure if in the planning process, organizing and providing parents are not involved. Parents of children with disabilities are beneficiaries of the support system for two reasons: on the basis of representation of the interests of their children, and on the basis of expressing their needs as guardian of his children. Therefore, the role of parents is manifold. They participate in identifying needs, establishing a connection between the needs and system of measures, participate in the process of service delivery, provide the necessary information institutions of the system, ensure the implementation of systematic measures for children, control the achieved results, have the responsibility and bear most of the burden related to the state of development problems of their children. This role of parents rises to the level of the central resources of the entire social support. In order for parents to become the real power and resources of the system of social protection is necessary to organize them as user associations. Users Association formally established non-governmental organizations aimed at representing the interests of its members, developing their capacities and strengthening of cooperation with institutions of public support systems. User's network association is a set of interconnected non-governmental organizations of parents of children with disabilities. They are working at the local level, in local communities. They collaborate with Centers for social work in every municipality on providing different types of support to children with disabilities and their parents.

\section{ACTION FRAMEWORK IN THE USERS ASSOCIATION AT SOCIAL WELFARE SYSTEM OF REPUBLIC OF SRPSKA}

The merits of the action of non-governmental organizations and users' association in the social security welfare system of the Republic of Srpska arise from the legal definition of a mixed system of social welfare. Social Protection Law (Official Gazette of Republic of Srpska, no. 37/12) defines the rights, measures and social services. Also, the law stipulates certain priority groups of users and operators of social protection. The same law stipulates that providing of social services can be realized in the public, private and NGO sector. This can be realized through mixed system of social welfare which enabled NGOs to participate equally in the implementation of the measures and social services. Basic characteristics of the mixed of social welfare system are: equality of public, private and non-governmental sector in planning, organizing and providing support services to users; a high level of involvement of user associations in the implementation of social protection measures; pluralism in setting priorities; Partnership in the development of public policy; development of social services on market principles, etc.

The reasons for the introduction of the NGO sector in the social welfare system of the Republic of Srpska lie in the fact that the existing capacity of the public sector in providing adequate responses to the needs of the user of social welfare system is insufficient. Resources of system for providing social support to children with disabilities are very scarce as can be concluded from the data that indicate: low budgets of public institutions, a lack of skilled staff, and poor development of existing and lack of new services. These shortcomings could be overcome or at least reduced with inclusion of the NGO sector in the social welfare system as a partner.

Cooperation and partnership of government institutions with NGOs is defined depending on the recognition of common interest and the nature of the area in which articulate the interests of certain groups of the population. The basis of the 
systemic recognition of the role and functioning of non-governmental organizations is located in the laws that define their establishment and operation. Effective laws on non-governmental organizations and foundations in the Republic of Srpska and Federation of Bosnia and Herzegovina are prescribed modes of formation, operation and functioning of nongovernmental organizations and foundations, their role and social significance. The law defines that children with disabilities are particularly vulnerable group of users that have priority in the offering of various types of social services. The most recognizable form of services used by children with disabilities is a Day care Centre. Some of them are even working in these facilities. This service was not recognized in the social welfare system in the previous period. Its development is fueled by the new Social Protection Law. Today this service represents the most respectable form of cooperation and partnership between public and non-governmental sectors. The most responsible for the development of these services are organization of parents of children with disabilities.

Special importance in the work of NGOs in this area has a municipal decision on extended rights. According to the Social Protection Law, each local community is required, shall decide on extended rights that define social services through which they have to meet social needs specific to the citizens and local community. Decision is making on basis of monitoring the state of social needs, in cooperation with their associations (Article 11). The purpose of this Decision is to provide services for their citizens that republican institutions are not recognized as a priority at the level of the entire system. The importance of non-governmental organizations in the design, implementation, monitoring and evaluation of the implementation of this Decision is large. Associations of parents of children with disabilities are most agile actors in these processes.

According to the Republic Bureau of Statistics annual influx of new cases of children with disabilities is about 1000 per annum (RSIS, 2016). However, the number of children who are beneficiaries of some of the rights from the social welfare system is much smaller. According to the Ministry of Health and Social Welfare that number is around three and a half thousand (Ministry of Health and Social Welfare, 2016), and the reasons must be sought in the restrictiveness of the existing system of social protection in the Republic of Srpska. Children with disabilities are the most common beneficiaries of the allowance for assistance and care of another person, the right to equalization of opportunities for children and youth with disabilities, the right to accommodation in an institution and the right to day care. As a particularly vulnerable group of beneficiaries, children with disabilities are also in the system of child protection which is entitled to child benefit under special criteria.

Actions of social and child protection in past are mainly been limited to the provision of financial support to families of children with disabilities and accommodation for children as well as direct specialist intervention. The lack of services in the social welfare system in the Republic of Serbian is a consequence of underdevelopment of institutions and problems in financing. Also, the reasons should be sought in cultural and historical heritage as well as the role of the family in the society. Republic of Srpska is still a patriarchal society that is experiencing intense transformation towards modern society, but they are still a strong traditionalist values in which the family and family authority plays a significant role.

The socialist system of social welfare did not include nongovernmental organizations. That system in the past relied exclusively on the role of the state and state institutions in the care of children with disabilities. Therefore, the forms and methods of work were poor by species. Although the state has a lot invested in the social welfare system, the needs of a significant number remained within the traditional forms of care, primarily in the form of financial transfers and classic institutional arrangements that are implemented in institutions for people with disabilities. System institutions were not interested in the development of non-institutional models of work with children with special needs. The role of parents was exclusively related to direct work with the child and parents were not recognized as a subject of support.

Disintegration of former Yugoslavia and the abandonment of the socialist system of social protection, this area has become an area of different influences competition in all spheres of life, including in the field of social and child protection. The application of international conventions and the intervention of international projects in the field of social and child protection has led to the adoption of new standards in this area which included an increased interest in the development of the NGO sector. This has opened the way for parents association to get in to interest groups that would later become a respectable part of systemic support (Lepir, 2010).

\section{ORGANIZATION OF PARENTS OF CHILDREN WITH DISABILITIES-NETWORK DEVELOPMENT}


Social welfare in Bosnia and Herzegovina became the area where the NGO sector made significant interventions, especially at the practical level. The implementation of a significant number of different projects that have left an indelible mark on the community level influenced the creation of the reform process at the system level. At first, only as strengthening the capacities of centers for social work and the introduction of new practices, later projects were started to influence the direction of reform processes in the entire system of social welfare. Good practice in a number of municipalities was confirmed as a good method of spreading the need to reform the existing practice in social welfare. At the beginning, exclusively financed by donor funds, project activities are becoming an integral part of the public budget which ensured the sustainability of good solutions for the beneficiaries.

One of the most important contributions of these projects, in addition to technical improvements of the system and practice, was to strengthen the partnership of the public and NGOs. It took a lot of time and activities to confirm this partnership into practice. Even now there are some doubts about the quality and functionality of the partnership, but it is not the fruit of mutual hostility between the two sides, but the realization that it is necessary to systematically arrange the place, role and functioning of these relationships (Lepir, 2009).

The action of the association of parents of children with disabilities has a long tradition in this region. The reasons for this lies in the fact that the fact that the developmental problems of children was understood exclusively as problems of parents. At the system level, these problems are treated as general social problems while the system institutions its procedures separated from the public. All this has affected the already built a stigma in society. The stigma that accompanied the family when it receives a child with disabilities prevented the exit of parents in public, and the activities of the institutions of the system was aimed exclusively at professional intervention while a whole problem walking away from the general public interest.

One of the most important contributions of these projects, in addition to technical improvements of the system and practice, was to strengthen the partnership of the public and NGOs. It took a lot of time and activities to confirm this partnership into practice. Even now there are some doubts about the quality and functionality of the partnership, but it is not the fruit of mutual hostility between the two sides, but the realization that it is necessary to systematically arrange the place, role and functioning of these relationships (Lepir , 2009).

The action of the association of parents of children with disabilities has a long tradition in this region. The reason for this is fact that the developmental problems of children were understood exclusively as problems of parents. At the system level, these problems are treated as general social problems while the system institutions its procedures separated from the public. All this has affected the already built a stigma in society. The stigma that accompanied the family when it receives a child with disabilities prevented the exit of parents in public, and the activities of the institutions of the system was aimed exclusively at professional intervention as a whole problem walking away from the general public interest

Organization of parents of children with disabilities in the Republic of Srpska began to form in the late 90s of the last century when it suddenly increased the interest of the general and professional public to the problems of this group of users in social welfare system. Very soon the work of local organizations has become known in local communities because it offered quicker, more accessible to the public and to the social welfare system, better insight to the real needs of children with disabilities and needs of their parents. A higher level of organization, and therefore more effective way of influencing the public social welfare system of the organization are achieved when, after a few years, joined the Alliance ( acronym "MENERALI") which has become an indispensable factor in planning, organizing and providing social support for children at the system level. In the early years, associations have emerged spontaneously on the basis of individual enthusiasts engagement, usually parents of children with disabilities, who are founding the association wanted to ease the problemsolving they faced in providing support to their children. The first interest of these associations was the problems of access to health care and social care. The first associations were mainly relied on the support of parents. Later, with the growing interest of international institutions in these issues, possibilities for project financing open up, that significantly speeds up the process of further strengthening the network of these associations.

Initially, these associations did not have the support of local centers for social work, as well as they did not have the support of local authorities. Over time, this picture has changed so that these associations become important partners in the planning, organization and implementation of measures and services for children with disabilities. Today, they are respectable resources on which social welfare system seriously account, especially in the provision of new services such as day care centers for children with disabilities. 
The biggest boost to the development of user organizations in this period gave the international projects of UNICEF, DFID and SDC. Their project interventions were aimed at supporting the establishment of parents' associations, strengthening the capacity of existing NGOs and the introduction and development of new services for children with disabilities. Later on in support of the development of a user network associations have been involved with the local community co-financing of new services that have been developed in these associations.

A significant step forward in the development of a network of non-governmental organizations in this area made the implementation of the action research "Early detection of children with special needs and their development problems," which was first implemented in the municipalities of Srbac, Prnjavor and Kozarska Dubica. During the next seven years (2002- 2008) this research was conducted in all municipalities in the Republic of Srpska (Lepir, 2006). For the first time this research was supported on behalf the Government of Republic of Srpska thru Ministry of Health and Social Welfare and the Public Fund for Child Protection, organizationally and financially. All activities that are conducted within this project were implemented in cooperation of center for social works and local associations of parents with disabilities. Activities were focused on conducting research on needs, sensitization of parents of children with disabilities for the purposes of greater social engagement, as well as strengthening social awareness to strengthen the support system at local level. The results achieved by the project are established in the new association of parents of children with disabilities in municipalities where there were none, technically and professionally have strengthened existing associations, explored the needs of families and children, established by the local database of children with disabilities, cooperation between the centers for social work and local associations, introduced new social services, established the first day care center for children with disabilities, raising the public awareness in local communities about the need for civic action in this area. During the Period of continuous implementation of this project, a significant number of families of children with disabilities received direct educational and advisory support on the specifics of the development problems of their child, and for child is provided the exercise of rights determined by Low, as well as measures and social services from social welfare system. The results of this project have been very important for the further development of a network of associations as well as to improve the overall social protection of children with disabilities in the Republic of Srpska.

Since 2010 there has been a decrease in interest of international institutions in this area in Bosnia and Herzegovina. At the same time local budgets have fallen into a crisis so that there has been a reduction of revenue of those organizations which contributed to the reduction of their activity. However, most organizations continued to work, to participate as a partner in the creation of social welfare at the local level and to influence the system solutions. A number of services have continued with work even though there is an interruption of funding from outside resources. At the end of 2015 in the Republic of Srpska there were about forty of these associations. Most of them (28) located in the roof MENERALI Union, while others operate independently.

Table 1. Classification of mentally and physically handicapped children and adolescents

\begin{tabular}{|c|c|c|c|c|c|c|}
\hline & & \multirow[t]{2}{*}{ Total } & \multicolumn{4}{|l|}{ Age } \\
\hline & & & "Under 7 years & $7-14$ & $15-16$ & $17-18$ \\
\hline \multirow[t]{14}{*}{ All } & 2011 & 1024 & 240 & 491 & 176 & 114 \\
\hline & Male & 580 & 138 & 284 & 92 & 66 \\
\hline & Female & 444 & 102 & 207 & 84 & 51 \\
\hline & 2012 & 1135 & 328 & 518 & 189 & 100 \\
\hline & Male & 658 & 205 & 291 & 112 & 50 \\
\hline & Female & 477 & 123 & 227 & 77 & 50 \\
\hline & 2013 & 1744 & 459 & 721 & 326 & 283 \\
\hline & Male & 970 & 247 & 402 & 192 & 129 \\
\hline & Female & 774 & 212 & 319 & 134 & 109 \\
\hline & 2014 & 1494 & 386 & 633 & 314 & 161 \\
\hline & Male & 852 & 215 & 344 & 188 & 105 \\
\hline & Female & 642 & 171 & 289 & 126 & 56 \\
\hline & 2015 & 1253 & 370 & 508 & 239 & 136 \\
\hline & Male & 679 & 194 & 281 & 128 & 76 \\
\hline
\end{tabular}


Source: Republic Institute for Statistics, 2016.

\section{RESEARCH RESULTS}

The results that will be presented were obtained in the study of the structure and organization of the user association's network. Research has been made in the period January-March 2017. The study included 21 non-governmental organizations which represent approximately $50 \%$ of all organizations that provide services for children with disabilities and their parents in the Republic of Srpska.

The subject of this research is the empirical analysis of the status, activities and resource of associations of parents of children with disabilities.

The aim of the research is to investigate a non-governmental network of support, membership structure and organization of users associations.

Hypothetical framework:

- Organization and management of associations are based on stakeholder integration motives and users actions.

- The work content of the association is based on the strengthening of existing and the introduction of innovative services in social protection.

- Association resources are insufficient to meet all the needs of users and are conditioned by the financial support of the local community.

- Association resources are insufficient to meet all the needs of users and are conditioned by the financial support of the local community.

\section{Research Methods:}

The study applied the basic, general, and data collection methods - methods of testing. Method of testing, the survey technique has been applied in empirical research also for the collection of data by questionnaire; instrument was designed for this study.

The questionnaire consists of 24 questions and 63 variables. The survey was completed by the most responsible persons at the associations. Processing of the results was performed by standardized statistical procedures.

\section{A) Organization and management of associations}

According to the Law on Associations and Foundations (Official Gazette of Republic of Srpska, 52/01), to establish association it is necessary that three individuals come together to achieve the objectives of the association. The association is in terms of this Act, any form of voluntary association of more natural or legal persons in order to improve or achieve some common or general interest or goal. Mandatory authority responsible for managing the association's is Assembly of the Association appointed by the Management Board or a person who represents the Assembly. Most people who represent these associations are also the parents of children with disabilities. Most often they are also the founders of the same association. In addition to the authorized person in the person, management usually involved a technical person engaged in correspondence, cash registers, running administrative affairs etc.

Managers of association of parents of children with disabilities are usually parents themselves. This fact talks about high level of integration between objectives of the association with its direct action. Associations gather children with disabilities, their parents and other people with disabilities. The structure of children and parents associations is diverse. In the study sample included a total of 521 families of which 397 or $76 \%$ have at least one of the high-educated parents. The number of families using cash transfers from the social welfare system is 240 or $46 \%$. Number of families who actively participates in co-financing of associations is 150. 
The largest number of associations over which the survey was conducted in his work is not often changed their managers. Half of these associations have so far had two managers, and only two associations have a brief break in their work which indicates a high degree of continuity in the work of the association.

According to the results, these associations bring together a total of 2,259 persons with disabilities, of which 665 children under the age of 18 years. Research results indicate that their members come from a variety of developmental and age groups. The largest number of members coming from groups of people with: psychiatric disorders (36\%), physical disability (10\%), damage of the musculoskeletal system (17\%) and visual impairment (10\%).

\section{A) Work contents of the association}

Most associations have opened Day care centers as an additional activity. The Day care center is an institution of social welfare or additional activity which provide day care. Daily care includes different types of organized daily services and stays out of your own family through which it provides nourishment, care, conservation, health care, upbringing and education, psychosocial rehabilitation, occupational therapy and other services. In term of Law there are different types of Day care centers which witch differs by the type and severity of developmental disorders in children. The activities of Day care center associations of parents of children with disabilities make a direct connection with the public system. The association administration in the implementation of Day care services provided by a partnership with the Centers for social work which entails obtaining equal status of social service providers in the local community.

These are activities that are offered in these associations and that should be highlighted: Professional work with children, Advisory work with parents, The daily child care/Day care center, Trips to nature, Birthday celebrations, Cultural and information activities, Regular gatherings of members/parents, The workshop activities/production of souvenirs, Rehabilitation/physical exercise, Sensitization of the public, Cooperation with other institutions in the municipality. Activity that are commonly practiced in an association is "professional work (1)", which implies the implementation of different types of professional intervention, such as speech therapy exercises, special treatment, psychological workshops and the like. Furthermore, it is present "counseling to the parents (2)" and "the rehabilitation services (9)," a least represented "cultural information activities (6)" and the "tours in the nature" (4). Graphic given below represents the earlier mentioned activities.

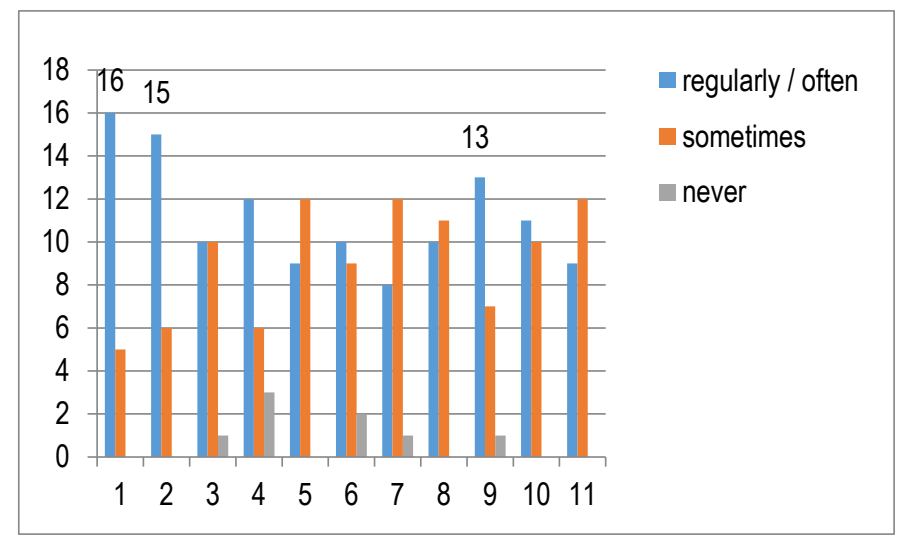

A significant part of the activity relates to the project implementation. It is interesting that all associations had experience in project activities. Most of these activities were related to "public sensitization projects" (90\%) and "parent education projects" $(90 \%)$. Associations have been dealing to in a lesser extent with projects related to children's leisure activities and projects that have established cooperation with other associations (81\%).

\section{A) Resources of the association}

Almost all of the associations involved in the research have the continuous support of professionals. Most of them are special education teachers of different directions, but there are psychologists as well. The support of professionals is very important in the work of these associations. This support raises the professional competence of the associations. In the 
beginning, this support was reduced, only as part of some project activities, but recently it has been a continuous support in direct work with children.

Most associations have working rooms, although they are often inadequate. In recent years, a number of associations have managed to build and equip new functional spaces for work, but this problem remains open. Often, the problem is the lack of equipment especially for those who are undergoing rehabilitation and work therapy.

Financing as the most important item of the association's resources has always been uncertain. However, analysis of the funds allocation of the governmental sector for the non-governmental sector in Bosnia and Herzegovina (B\&H) for 2007 and 2008, carried out by IBHI (2009), found that a significant part of the funds from the government budgets were allocated to the work and activities of the entire non-governmental sector. Compared to 2007, these allocations in B\&H increased by about 11 million KM. Most of the funds come from the level of municipal budgets. A certain part of the funds is allocated from appropriately collected funds from the profit of games of chance. Organizations with a special status (veteransdisabled associations, refugee associations, etc.) are financed directly from the budget (usually the entity budgets of Republic of Srpska or Federation of Bosnia and Herzegovina), exclusively based on program activities. Organizations of persons with disabilities (associations) receive grants intended for humanitarian activities also on the basis of program activities. The competitive allocation of funds to non-governmental organizations has not yet become overwhelming, which indicates possible further improvements in financing methods. According to research findings, the ways in which funds are allocated to non-governmental organizations are not based on public call procedures (tenders). As much as $41 \%$ of the institutions allocate these funds on the basis of insights into the program activities of organizations. Only a fifth institution applies tender procedures (IBHI, 2009).

In 2007, around 107 million KM were planned at different levels of government in B\&H, which represents $0.55 \%$ of GDP for 2007 (in 2008, 118 million KM were planned). A little over 50\% was allocated for sports and veterans' organizations. For other types of organizations, these allocations ranged from $43 \%$ in 2007 to $48 \%$ in 2008. Organizations that are certified as social service providers have been invested about $14 \%$ of the total allocated funds to all non-governmental organizations, which shows that most of the funds go to organizations whose activities are not proactively targeted for social inclusion activities. The funds intended for the provision of social protection services are still insufficient according to the required level of needs (Lepir, 2009).

A survey carried out among associations of parents with disabilities in the Republic of Srpska found that there is not only one way of financing. Funding of these associations is provided from multiple sources. The largest number of associations provides funds through donations from the private sector and through grants from local government institutions. Funding of associations from projects is one of significant item in the budgets of these associations. The largest number of associations participated in the projects as a partner organization. A small number of associations appeared as a project leader, so the funds on this basis were small. Small part of funds are from personal donations of families whose children use the services of the association Membership fees as a source of funding do not apply in the work of these associations. The diversity of sources of funding enables associations to provide the means necessary for maintaining basic activities, and also does not allow development of new, and improvement of existing social services.

\section{CONCLUSIONS}

The network of the Association of Parents of Children with Special Needs in the Republic of Srpska are developed under the influence of international organizations' projects and the, as well as gradual development of awareness of the importance of community involvement. Associations have crossed the road from the period when they were driven by the enthusiasm of parents to a legally positioned place in system solutions. In parallel with the implementation of projects that advocated partnership relations between the public and non-governmental sectors, awareness in the community of the need to organize user associations and their role in achieving better quality of social protection has grown. As a result of these processes, it was the establishment of a mixed social protection system that opened the door to users associations for public policy participation that regulated social support for children with disabilities. Misunderstandings between centers for social work and parents' associations with disabilities were overcome, but the question of establishing adequate and functional coordination and cooperation remained. However, on the other hand, their importance has been recognized in the public from local communities. Associations have become a subject in the social protection of children with disabilities. Strengthening the competencies of parents, their association and the activities of associations in the social protection 
system have achieved much in the field of recognizing the real needs of children with disabilities and establishing a more efficient social services system.

The survey of the network of parents' organizations with disabilities has shown that these user associations are poor with resources, lacking adequate financial support and still having problems with lack of professional competencies in working with users. However, a constant increase in the number of these organizations indicates the need for their action. According to this statement we ask the question: Does Social Welfare system helps in developing a non-governmental network of support for children with disabilities? Serenely, yes. But is it enough? Benefits of involving user associations in the social protection system are found in: faster, more economical, more direct and more accessible social services; more flexible and rational organization of services; the possibility of creating new services based on the real needs of users; greater choice of services as well as ability to engage more resources in the local community.

The most recognizable activity of non-governmental organizations lies in the provision of direct services to children and educational and informative work with parents and the general public. User associations influence public opinion and provide support to the public of local communities, which has a direct impact on the sustainability of their work. Their significance lies in analytical-research activities, the analysis of the state of the state of resources in the field and the recognition of the real needs of families and their children.

User associations represent the best guarantor in representing the interests of children with disabilities and their parents. Their future development will be conditioned by: strengthening of the partnership relations with the public institutions of the system; the introduction of standards in the provision of social services, the professionalization and specialization of nongovernmental organizations in this field and the provision of a secure source of funding.

\section{References}

[1] IBHI. (2009). Izdvajanja vladinog sektora za nevladin sektor u BiH za 2008 godinu - 118 miliona koraka do saradnje. Sarajevo: IBHI.

[2] Lepir, LJ. (2006). Društvena briga o djeci sa posebnim potrebama: Socijalna misao, br. 50.

[3] Lepir, LJ. (2009). Jačanje profesionalnih kapaciteta nevladinih organizacija. Sarajevo: IBHI

[4] Lepir, Lj. (2010). Socijalna zaštita Republike Srpske. u: Gavrilović, A. ed. Socijalni izazovi i menadžment u socijalnoj zaštiti. Banja Luka: Fakultet političkih nauka

[5] Lepir, Lj., Šćepović, D., Gajić, D., Šeranić, A i Jovanović, S. (2010). Socijalna, porodična i dječija zaštita u Republici Srpskoj. Banja Luka: Ministarstvo zdravlja i socijalne zaštite Republike Srpske.

[6] Lepir, Lj. i Šćepović, D., (2016). Akcioni pristup socijalne zaštite u radu sa djecom sa posebnim potrebama i njihovim roditeljima. Kniga sažetaka. u: Beogradska defektološka škola, 2/16, Vol 22.str: 71.

[7] MZSZ. (2016). Bilten socijalne, porodične i dječije zaštite. Banja Luka: Ministarstvo zdravlja i socijalne zaštite Vlade Republike Srpske

[8] Pravilnik o ostvarivanju prava na dnevno zbrinjavanje („Sl. glasnik RS“, br. 2 /14)

[9] Pravilnik o procjeni potreba i usmjeravanju djece i omladine sa smetnjama u razvoju („Sl. glasnik RS“, br. 117 /12).

[10] RZS RS. (2016). Bilten socijalne zaštite, Banja Luka: Republički zavod za statistiku

[11] Zakon o dječijoj zaštiti ( „Sl.glasnik Republike Srpske“, br. 4/02, 17/08 i 1/09).

[12] Zakon o socijalnoj zaštiti (SI. glasnik RS. br. 37/12, 90/16)

[13] Zakon o udruženjima građana i fondacijama (Službeni glasnik, 23/11) 